\title{
Feeding response of the polychaete Sabellaria alveolata (Sabellariidae) to changes in seston concentration
}

\author{
Stanislas Dubois ${ }^{a,{ }^{*}}$, Laurent Barillé ${ }^{\mathrm{b}}$ and Bruno Cognie ${ }^{\mathrm{b}}$
}

\begin{abstract}
${ }^{a}$ French Research Institute for Exploration of the Sea (IFREMER), DYNECO Ecologie Benthique, Technopole de Brest-Iroise, BP 70, 29280 Plouzané, France

${ }^{b}$ Mer Molécules Santé (MMS), UPRES-EA 2160, Faculté des Sciences, Université de Nantes, 44322 Nantes Cedex 3, France
\end{abstract}

*: Corresponding author : S. Dubois, email address : Stanislas.Dubois@ifremer.fr

\begin{abstract}
:
Sabellaria alveolata is a tube-building gregarious polychaete that constructs large biogenic reefs. In macrotidal shellfish ecosystems, this species competes for food with cultivated suspension-feeders. The suspension-feeding activity and clearance rate of $S$. alveolata were investigated in response to changes in seston concentration. A flow-through system was designed to study $225 \mathrm{~cm}^{2}$ reef blocks with more than 500 individuals. The experimental conditions were characterized by increasing concentrations of suspended particulate matter ranging from 6.5 to $153.8 \mathrm{mg} \mathrm{L}^{-1}$, while the organic content of the diet (microalgae Skeletonema costatum) decreased inversely from 49 to $9 \%$, to mimic the dilution of organic matter by inorganic particles, characteristic of tidal resuspension. We showed that the clearance rate exponentially decreased in relation to an increase in SPM concentration. Clearance rate was estimated at $5.310^{-3} \mathrm{~L} \mathrm{~h}^{-1}$ or $0.93 \mathrm{~L} \mathrm{~h}^{-1} \mathrm{~g}^{-1}$ (dry weight) for the lowest seston concentration (SPM $=6.5 \mathrm{mg} \mathrm{L}^{-1}$ ) and reached the asymptote at $\mathrm{CR}=1.9710^{-3} \mathrm{~L} \mathrm{~h}^{-1}$ or $0.35 \mathrm{~L} \mathrm{~h}^{-1}$ $\mathrm{g}^{-1}$ (dry weight) when SPM exceeded $45 \mathrm{mg} \mathrm{L}^{-1}$. Using picture analyses of polychaete movements, we showed that, paradoxically, an increase in SPM concentration did not adversely affect the feeding activity of $S$. alveolata since the number of filtering individuals remained stable from SPM $=6.5$ to $55.5 \mathrm{mg} \mathrm{L}^{-1}$. These values were applied at the scale of the bay of Mont-Saint-Michel (France) to demonstrate that the filtration pressure of large populations of wild suspension-feeders should not be underestimated when the carrying capacity has to be assessed in the context of increasing bivalve cultures.
\end{abstract}

Keywords: Feeding activity; Reefs; Suspension-feeders; Trophic capacity; Tubiculous polychaete; Bay of Mont-Saint-Michel

\section{Introduction}

Sabellaria alveolata is a tube-building suspension-feeding polychaete, widely distributed on European coasts from the Bristol Channel to the Portuguese coast ([Dubois et al., 2002] and [Dubois et al., 2006a]). In fact, it builds the largest biogenic formations on the European coast (Holt et al., 1998). Bioconstructions of $\mathrm{S}$. alveolata are colonies typically found as veneers adhering to rocky shores at the mid-level of the intertidal zone. However, the largest structures are found in rare locations where these reefs can cover extensive areas on sandflats in the lower intertidal zone. In the bay of MontSaint-Michel, S. alveolata reefs create irregularly-shaped, patchy banks that cover approximately 100 ha and are considered the largest reef in Europe (Gruet and Bodeur, 1997 Y. Gruet and Y. Bodeur, Les récifs d'Hermelles. In: J.C. Dauvin, Editor, Les biocénoses marines et littorales françaises des côtes Atlantiques, Manche et Mer du Nord, synthèse, menaces et perspectives, Service du Patrimoine Naturel / IEGB / MNHN Paris Publishers (1997), pp. 168-176.Gruet and Bodeur, 1997). These biogenic reefs are 
poorly understood, including their role in the trophic web of the ecosystem they inhabit. In the particular case of the bay of Mont-Saint-Michel, where the cultivation of oysters

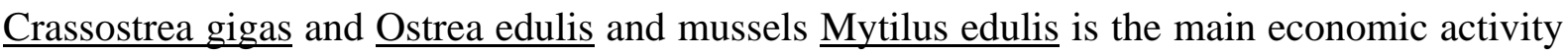
(Le Mao et al. 2004), the question of the carrying capacity is of primary importance in a system largely dominated by benthic suspension-feeders (Cloern, 1982). In this bay, the large biogenic reefs (i.e. over 100 ha and up to 60,000 ind $\mathrm{m}^{-2}$ ) might be seen as a significant biological filter. In that context, measurement of the feeding activity of $\underline{S}$. alveolata is a necessary step to assess the effects of biogenic reefs at the bay scale, compared with that of other cultivated and wild suspension-feeders.

In intertidal areas, filter-feeding organisms are greatly exposed to rapid changes in the availability and nutritional value of suspended particulate matter (hereafter SPM or seston). Because of the local action of wind- or tide-induced currents, the resuspension of sedimentary material, causing short-term variations in inorganic particles, may considerably modify the relative organic concentration of seston available to suspension-feeders. Understanding the effects of seston variations on feeding activity and filtration rates is an important goal in order to evaluate accurately the filtration of suspension-feeders in turbid macrotidal ecosystems. Suspension-feeder responses to changes in seston concentration have revealed a complex set of physiological (Barillé et al., 1997; Navarro and Widdows, 1997), morphological (Barillé et al., 2000; Dutertre et al., 2007) and behavioral adaptations (Iglesias et al., 1996; Newell et al., 2001; Riisgård et al., 2003). While bivalves and gastropods have been widely studied (see references above), much less is known about other taxonomic groups such as polychaetes (but see Jordana et al., 2001; Riisgård et al., 2002; Hentschel and Larson, 2005), yet these are the most abundant and diverse group in estuarine and marine environments. Although Dubois et al. (2005) have studied the mechanisms of particle capture and processing in polychaetes 
75 Sabellaria alveolata, the effects of seston variations on filtration and feeding activity have not been investigated.

Because of its wide variety of depositional sedimentary environments and its macrotidal-related hydrological features, the bay of Mont-Saint-Michel is characterized by a broad range of suspended particulate matter. Recently, Cayocca et al. (2008) surveyed the sedimentary processes in a shellfish farming environment in the vicinity of the largest $\underline{S}$. alveolata reef: while SPM peaks ranged between 200 and $1000 \mathrm{mg} \mathrm{L}^{-1}$ depending on the flow and ebb conditions, SPM concentrations remained around $50 \mathrm{mg} \mathrm{L}^{-1}$ over most of the tide

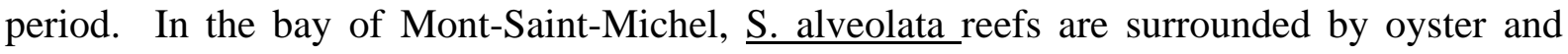
mussel farming structures (Fig. 1), potentially filtering the same food sources but also locally increasing biodeposition rates and hence SPM concentrations. In this bay, largest mudflats and highest SPM concentration are hence found in the closest proximity to shellfish farming structures (Ehrhold et al., 2003). Using troughs specially designed to allow experimentation on large reef blocks, the objectives of this study were thus (1) to investigate feeding responses

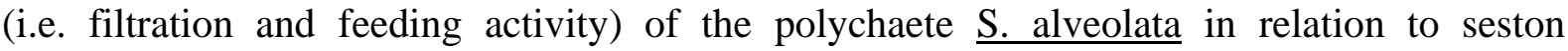
concentration and (2) to evaluate the filtration of $\underline{S}$. alveolata reefs in the bay of Mont-SaintMichel in comparison with the filtration of the main cultivated and natural suspension-feeding species.

\section{Materials and methods}

\subsection{Sampling and conditioning of Sabellaria alveolata}

Portions of reef were taken from the reef located in the eastern part of the bay of Mont-Saint-Michel (i.e. Champeaux reefs $1^{\circ} 29^{\prime} 28.2^{\prime}{ }^{\prime} \mathrm{O} / 48^{\circ} 41^{\prime} 1.15^{\prime \prime} \mathrm{N}$; Fig. 1). Samples 
were extracted with a metal corer of $225 \mathrm{~cm}^{2}$ surface area $(15 \times 15 \mathrm{~cm})$ and $15 \mathrm{~cm}$ depth, corresponding to the reef layer where Sabellaria alveolata lives (Gruet, 1971). Five reef blocks were collected under similar environmental conditions (sedimentary processes, hydrodynamics, bathymetry). Mud deposits were carefully removed in seawater then samples were put in an aquarium containing natural seawater with an open circuit kept at a constant

105 temperature $\left(15^{\circ} \mathrm{C}\right)$. Individuals were fed algal cultures of Skeletonema costatum, a ubiquitous diatom widely found in European coastal waters and used in bivalve aquaculture (Barillé et al., 2003). During the acclimation period, dead individuals of $\underline{\mathrm{S}}$. alveolata were removed. Attention was also paid to associated species occurring in micro-crevices, such as small molluscs, other polychaetes or nemerteans; these were extracted from reef blocks to avoid disturbance and to assure that the measured filtration was only due to $\underline{S}$. alveolata individuals.

\subsection{Experimental equipment}

A flow-through system was designed to measure Sabellaria alveolata feeding responses based on an experimental set-up used with suspension-feeding bivalves and polychaetes (Palmer \& Williams, 1980; Barillé et al., 1993; Ropert and Goulletquer, 2000). Each block was placed in a $10 \mathrm{~L}$ trough with a $2 \mathrm{~L}$ flow-through chamber (volume used for filtration measurements) (Fig. 2). There was no connection between the flow-through chamber and the rest of the trough, keeping the whole reef block under water.

The system, consisting of a set of 6 troughs connected in parallel, received filtered seawater $(0.45 \mu \mathrm{m}$ Millipore R.A. filters) mixed in a 200 -liter tank with the experimental diets (Fig. 2). The particulate organic matter (hereafter POM) supplied to the polychaetes was composed of the diatom Skeletonema costatum, kept in the culture collection of the Marine 
125 Biology Laboratory of the Science Faculty in Nantes and grown in a culture room (temperature: $14^{\circ} \mathrm{C}$, light/dark: $14 / 10 \mathrm{~h}$, light intensity: $100 \mu \mathrm{mol}$ photon $\mathrm{m}^{-2} \mathrm{~s}^{-1}$ ). Silt (Kaolinite BS1, AGS, Montguyon, France) was added to the algal culture to simulate particulate inorganic matter (hereafter PIM) and thus span an increasing range of suspended particulate matter (SPM). Five experimental conditions were tested (C1 to C5) based on the observed range of SPM values in the bay of Mont-Saint-Michel (Cayocca et al., 2008). One trough containing a reef block without polychaetes was used as a sedimentation control (i.e. the outflow of the control trough was used to represent the inflow in troughs with polychaetes). Prerequisites for using flow-through chambers were tested according to the recommendations of Riisgård (2001). The flow rate was adjusted with Gilmont ${ }^{\circledR}$ flow-meters 135 to between 2 and $3 \mathrm{~L} \mathrm{~h}^{-1}$ - under 1 atm and at $20^{\circ} \mathrm{C}$ - according to the experimental conditions.

\subsection{Measurements of feeding activity}

To assess the number of filtering individuals precisely, a remote-controlled high resolution CDD camera ( $310^{6}$ pixels) was fixed on a frame above the troughs, so that pictures of any trough could be taken without disturbing the polychaetes during the course of the experiment. One picture of the reef surface was taken every 6 minutes for one hour in one randomly selected trough. Because of light penetration in the water above the reef blocks,

145 only the experimental conditions with $\mathrm{SPM} \leq 50 \mathrm{mg} \mathrm{L}^{-1}$ (i.e. $\mathrm{C} 1$ to $\mathrm{C} 3$ ) enabled a reliable interpretation of the pictures. Digital pictures were processed according to a two-step standardized protocol, using image processing software Adobe ${ }^{\circledR}$ Photoshop-CS3 ${ }^{\circledR}$ (Fig. 3): (1) a picture of each reef surface was reshaped to the size of the reef block (i.e. $15 \mathrm{~cm}$ x $15 \mathrm{~cm}$ ) and used as a reference to map all the tube apertures (empty circles) and to obtain an empty 
grid (Figs. 3a to 3d); (2) the map of the tube apertures was superimposed on each picture taken during the course of the experiment and empty circles containing a filtering polychaete were color-coded in black before all empty circles were removed (Figs. 3e and 3f). It was easy to determine whether or not a tube aperture contained a filtering polychaete because of the whitish color of the prostomium bearing tentacular filaments (see pictures in Dubois et al., 2005). To quantify the number of individuals that switched from a feeding mode to a nonfeeding mode between two pictures, two successive color-coded maps of filtering polychaetes were superimposed by deleting all common filled circles (Fig. 4).

\subsection{Measurements of filtration}

160

Reef blocks were placed in experimental conditions 1 hour before any measurement. Particle size distributions were determined using a Multisizer particle counter fitted with a $100 \mu \mathrm{m}$ aperture. Particle counts were carried out with coefficients of coincidence $<5 \%$. All particle sizes were expressed as Equivalent Spherical Diameter (ESD). Clearance rate was calculated 165 with particles above a threshold of $6 \mu \mathrm{m}$ ESD, shown in previous studies (Dubois et al., 2003) to be cleared with $100 \%$ efficiency. Considering the mean flow in individual troughs, the clearance rate $\left(\mathrm{L} \cdot \mathrm{h}^{-1}\right)$ was calculated as:

$$
\mathrm{CR}=[(\text { inflow-outflow }) / \text { inflow }] * \text { flow rate }
$$

After experiments, all individuals were killed in $4.5 \%$ formalized seawater. Tubes

170 were disintegrated in seawater. All $\underline{\text { Sabellaria alveolata individuals were collected counted }}$ and their weight was estimated after drying for $48 \mathrm{~h}$ at $60^{\circ} \mathrm{C}$.

\subsection{Seston concentration}


The amount of SPM, PIM and POM in the diet was obtained by the loss-on-ignition method. Water samples were filtered on pre-weighed $\mathrm{GF} / \mathrm{F}$ filters dried at $60^{\circ} \mathrm{C}$ for $24 \mathrm{~h}$ for SPM determination. POM was estimated as the filter weight loss after subsequent ignition of samples $\left(450^{\circ} \mathrm{C}\right.$ for $\left.4 \mathrm{~h}\right)$. PIM was deduced from the difference between these two measurements. POM concentrations were corrected for the loss of Kaolinite structural water 180 (Barillé-Boyer et al., 2003). Experimental conditions are shown in Table 1.

\subsection{Statistical analysis}

One-way ANOVA was used to test for differences in clearance rate and filtering

185 activity between experimental conditions. Data were accordingly checked for normality and homogeneity of variance. A significance level of $p<0.05$ was used in all tests. When significant, pairwise post-hoc comparisons were performed using the Tukey HSD test. Variations in CR were fitted against SPM using an exponential decay curve $\mathrm{CR}=\mathrm{CR}_{0}+\mathrm{a} \times$ $\exp ^{(-\lambda \mathrm{SPM})}$, where $\mathrm{CR}_{0}$ is the asymptotic $\mathrm{CR}$ value, a is the intercept, and $\lambda$ is the slope. 190 Parameter estimation was achieved with Sigmastat 2.0 by using the downhill simplex method. All curve fittings between CR observations and the asymptotic model were tested by analyses of variance $(\mathrm{p}<0.05)$.

\section{Results}

\section{$\underline{\text { 3.1. Filtering activity }}$}

After destruction of the reef blocks, the collection of all individuals revealed that the estimated number of worms using image analysis (i.e. with tube apertures) was very close to 
the actual number of worms (Table 2). The mean difference between the counted tube apertures and the actual number of polychaetes found in each reef block $(3.12 \%, \mathrm{SE}=1.60)$ indicated that the image analysis provided a good estimate of the number of potentially filtering polychaetes. After destruction and drying, the mean dry weight for a reef block was $3.18 \mathrm{~g}(\mathrm{SE}=0.11)$ for a mean number of 576 individuals $(\mathrm{SE}=13)$.

Overall, between 40 and $50 \%$ of polychaetes were filtering during the course of the experiment, whatever the experimental conditions (C1 to $\mathrm{C} 3$ ) (Fig. 5a). A significantly lower percentage for the mean of filtering polychaetes (43.2\%; Tukey, $\mathrm{p} \leq 0.009$ ) was noticed for $\mathrm{C} 1\left(\mathrm{SPM}=6.5 \mathrm{mg} \mathrm{L}^{-1}\right)$ compared to $\mathrm{C} 2\left(46.3 \% ; \mathrm{SPM}=12.3 \mathrm{mg} \mathrm{L}^{-1}\right)$ and $\mathrm{C} 3(47.4 \% ; \mathrm{SPM}=$ $55.5 \mathrm{mg} \mathrm{L}^{-1}$ ) (Fig. 5a). Between two pictures of filtering activity (Fig. 5b), from 5 to $10 \%$ of 210 individuals (ca. 40 to 50 individuals) switched from a feeding to a non-feeding mode, or vice versa. This number did not differ significantly in relation to the experimental conditions (ANOVA, $\mathrm{p}=0.057$ ) (Table 3), even though it was slightly higher for the condition C3 at the beginning of the experiment.

\subsection{Filtration in relation to SPM concentration}

Size spectra obtained using the particle counter typically showed 3 peaks (Fig. 6) at the outflow of the troughs: peak C corresponded to the microalgae $\underline{\text { Skeletonema costatum, }}$ spanning between 7 and $16 \mu \mathrm{m}$ ESD, peak B to Kaolinite calibrated particles (3-4 $\mu \mathrm{m} \mathrm{ESD)}$ while peak A was unexpected. Microscopy analysis revealed that it corresponded to spermatozoa (2-3 $\mu \mathrm{m}$ ESD). As a result, clearance rates (CR) were calculated using the 6-16 $\mu \mathrm{m}$ ESD size range, ensuring that all particles were cleared with $100 \%$ efficiency.

Clearance rates significantly decreased (ANOVA, $\mathrm{p} \leq 6.1710^{-4}$ ) with increasing seston concentrations (Fig. 7). The highest $\mathrm{CR}$ of $1.28 \mathrm{~L} \mathrm{~h}^{-1}$ per reef block was estimated for 
$225 \mathrm{C} 1$ (without Kaolinite) and subsequently decreased for $\mathrm{C} 2\left(\mathrm{PIM}=9.5 \mathrm{mg} \mathrm{L}^{-1}\right)$ to $0.88 \mathrm{~L} \mathrm{~h}^{-1}$ per reef block. Clearance rates remained below $0.7 \mathrm{~L} \mathrm{~h}^{-1}$ per reef block for $\mathrm{C} 3$ to $\mathrm{C} 5$, without significant changes. The $\mathrm{CR}$ of reef blocks standardized with the percentages of filtering individuals (assuming this percentage did not change from C3 to C5) varied from 2.96 L.h ${ }^{-1}$

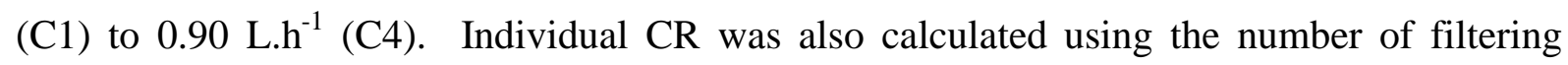
230 polychaetes and a functional relationship was established between CR and SPM using an exponential decay curve (Fig. 8). The model showed a sharp decrease in individual CR in the SPM range 0-20 mg L $\mathrm{L}^{-1}$, followed by an asymptotic value around $210^{-3} \mathrm{~L} \mathrm{~h}^{-1} \mathrm{ind}^{-1}$. The influence of SPM concentration on CR was hence expressed by the following equation:

$$
\mathrm{CR}=1.9710^{-3}+8.6110^{-3} \mathrm{e}^{-0.146 \times \mathrm{SPM}} \quad\left(\mathrm{R}^{2}=0.951 ; \mathrm{p}<0.05\right)
$$

235 Considering an individual dry weight of $5.6 \mathrm{mg}$ (see Table 2), the individual CR was estimated at $5.310^{-3} \mathrm{~L} \mathrm{~h}^{-1}$ or $0.93 \mathrm{~L} \mathrm{~h}^{-1} \mathrm{~g}^{-1}$ (dry weight) for the initial condition (no Kaolinite, $\mathrm{SPM}=6.5 \mathrm{mg} \mathrm{L}^{-1}$ ) and reached the asymptote at $\mathrm{CR}=1.9710^{-3} \mathrm{~L} \mathrm{~h}^{-1}$ or $0.35 \mathrm{~L} \mathrm{~h}^{-1} \mathrm{~g}^{-1}$ (dry weight) when SPM exceeded $45 \mathrm{mg} \mathrm{L}^{-1}$.

\section{Discussion}

The effect of seston concentration on suspension-feeder activity and/or clearance rates has been widely discussed in the literature (see, for example, Shumway et al., 1985; Bayne et al., 1989; Navarro and Widdows, 1997; Barillé et al., 2006) but investigations have focused mainly on mollusc species in general and bivalves in particular. In that context, the Pacific

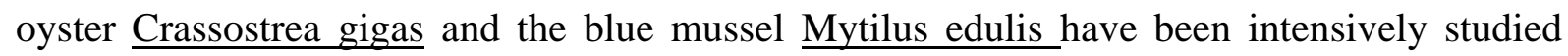
(e.g. Barillé et al., 1997 and references therein). This research has revealed a complex set of physiological and morphological adaptations to high SPM concentrations: clearances rates have been shown to decrease in response to increasing particle concentration and several 
measurements have demonstrated complex mechanisms of particle processing and sorting to maintain feeding rates under high SPM concentrations and to limit clogging of the gills (Barillé et al., 2000). Similar behavioral adaptations have been shown in other mollusc species such as sea scallop Placopecten magellanicus (Cranford and Gordon, 1992), the cockle Cerastoderma edule (Navarro and Widdows, 1997), the slipper limpet Crepidula 255 fornicata (Barillé et al., 2006), and the clam Mercenaria mercenaria (Bricelj and Malouf, 1984). However, the effects of seston concentration have been rarely investigated in other taxonomic groups, notably polychaetes. Spionids (Polychaeta: Spionidae), facultative suspension- or deposit-feeders, are the most studied polychaete group (e.g. Bock and Miller, 1996; Hentschel and Larson, 2005) but other polychaete families remain far less examined.

\subsection{Particle loads and feeding activity of Sabellaria alveolata}

Very few changes were noticed in Sabellaria alveolata behavior in relation to SPM concentration. While increasing seston loads is commonly known to hamper suspension-

265 feeder filtration activity, we found a significant increase in the number of active polychaetes between $\mathrm{SPM}=6.5$ and $12.3 \mathrm{mg} \mathrm{L}^{-1}$ and no change between $\mathrm{SPM}=12.3$ and $55.5 \mathrm{mg} \mathrm{L}^{-1}$. We initially hypothesized a decrease in the number of filtering polychaetes or a higher turnover rate in polychaetes switching between filtering and non-filtering modes, as evidence of SPM disturbances. On the contrary, less than $10 \%$ of individuals were switching between 270 two snapshots, whatever the experimental conditions. These limited changes are probably due to natural inter-individual interactions forcing polychaetes to withdraw into their tubes, and do not reflect any physical constraints linked to increasing SPM. A small but significant increase in the percentage of filtering worms was even noticed when Kaolinite was added to the diet $\left(\mathrm{SPM}=12.3 \mathrm{mg} \mathrm{L}^{-1}\right)$. Flow speed is known to stimulate suspension-feeding activity 
275 and to induce a switch between deposit-feeding and suspension-feeding modes in spionids (Taghon et al., 1980; Eckman and Duggins, 1993). Higher water velocities increase resuspended material and hence seston concentrations. We have shown here that SPM loads

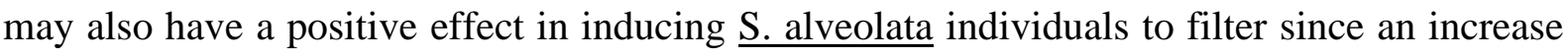
in filtering individuals was evidenced for $\mathrm{SPM}$ value $<50 \mathrm{mg} \mathrm{L}^{-1}$. For technical reason, it 280 was not possible to determine effects of higher SPM loads and further hypotheses would have been too speculative.

Previous experiments using video-endoscopy (Dubois et al., 2005; Dubois et al., $2006 b)$ revealed that $\underline{S}$. alveolata exhibits several mechanisms related to pre-ingestive particle processing: (1) bi-directional particle transport on the tentacles, acting as a preliminary 285 sorting mechanism before collection in food grooves, (2) pseudofeces production allowing individuals to reject excess particles before ingestion and (3) contribution of two peribuccal palps to clean up filamentary tentacles when overloaded. All these mechanisms probably contribute to maintain feeding activity under high seston concentration.

An automated video system has previously been developed to quantify the feeding 290 activity of a small batch (12 to 15 individuals) of non-gregarious serpulid polychaetes Ditrupa arietina (Duchêne et al., 2000; Jordana et al., 2000). Such an automated system is not suitable for studying reef blocks with hundreds of individuals. Besides, using a large number of individuals enables a better estimate of inter-individual and intra-population activity (Dubois et al., 2003). Experiments on D. arietina revealed a strong inter-individual variability in the 295 filtering activity: worms filtered neither continuously nor according to a particular rhythm, and no relationship was found between POM and filtration activity (Jordana et al., 2000). $\underline{\text { S. }}$ alveolata appears to have a steadier filtering activity: otherwise, a larger percentage of worms would have switched between filtering and non-filtering modes. Probably because of the above-mentioned mechanisms - which have not been shown in serpulid polychaetes $-\underline{S}$. 
alveolata is adapted to turbid systems and can maintain its filtering activity under high seston loads. This is particularly important for an intertidal species, since the highest SPM concentrations are encountered at the beginning of the flow and at the end of the ebb tides (Cayocca et al., 2008).

Reports on the effects of seston on polychaete clearance rates remain very scarce in the literature. Riisgård et al. (2002) showed that an increase in algal concentration corresponded to a decrease in clearance rate for both Ditrupa arietina and Euchone papillosa (Polychaeta: Sabellidae): a 5-fold increase in POM led to a minimum 50\% decrease in clearance rate in these species, presumably because of limits in the gut capacity. Hentschel and Larson (2005) measured that the growth rate of interface-feeding spionid polychaetes (facultative suspension/deposit feeders) was differently affected by flow speed and the accordingly modified concentration of suspended food particles. In this study, we have 315 shown that the clearance rates (CRs) of Sabellaria alveolata are adversely affected by an increase in SPM. The decrease appeared to be sharp for SPM $<45 \mathrm{mg} \mathrm{L}^{-1}$ while CR reached a plateau for higher SPM values. Such a relationship, modeled by a decreasing exponential function, is typical of animals living in intertidal areas (Barillé et al., 1997; Navarro and Widdows, 1997). Considering the feeding activity results - i.e. no adverse effect of SPM on 320 the number of filtering individuals - the relationship between CR and SPM indicates that a larger number of individuals are filter-feeding but that individual clearance rates are lower. In suspension-feeding invertebrates, SPM has two types of effect: (1) it induces regulation mechanisms to cope with SPM loads (pre-ingestive sorting and production of pseudofeces) and (2) it provokes a cessation of filtration due to physical constraints on the sorting organs 
325 (e.g. clogging of gills). In this study, as filtration activity was not altered at high SPM concentrations (ca. $100 \mathrm{mg} \mathrm{L}^{-1}$ ), we hypothesize that the decrease in clearance rates was due to the gut capacity.

A preliminary estimate of Sabellaria alveolata $\mathrm{CR}$ was $0.75 \mathrm{~mL} \mathrm{~h}^{-1}$ ind $^{-1}$ (Dubois et al., 2003), which is 7 to 2.5 times less than the CRs estimated in this study, for a condition 330 without Kaolinite and a condition with $\mathrm{SPM}>45 \mathrm{mg} \mathrm{L}^{-1}$ respectively. Such a difference is not only due to the assumption in Dubois et al. (2003) that all the worms were filtering (ca. 2 times error factor). We suggest here that the difference with the Dubois et al. (2003) experiment is also due to the physiological state of the polychaetes, and more precisely the reproductive state, since the former experiment was carried out in winter (when individuals were under minimal physiological requirements and activity), while samples for this study were extracted in spring. As an example, Bruschetti et al. (2008) recently showed that the seasonal grazing effect of the reef-forming polychaete Ficopomatus enigmaticus (Serpulidae) on phytoplankton was ca. 3 times lower in winter (19\%) than in summer (56\%). The clearance rate values obtained here can be compared with CRs for other polychaetes, even if 340 the experimental conditions and CR calculations often remain different. At the plateau, $\underline{S}$. alveolata $\mathrm{CR}$ was estimated at $0.35 \mathrm{~L} \mathrm{~h}^{-1} \mathrm{~g}^{-1}$ dry weight (or $0.065 \mathrm{~L} \mathrm{~h}^{-1} \mathrm{~g}^{-1}$ fresh weight). These values are about one order of magnitude lower than CRs calculated using colloidal graphite suspension by Dales (1957) for sabellids (Sabella pavonina and Myxicola infundibulum, 0.39 and $0.10 \mathrm{~L} \mathrm{~h}^{-1} \mathrm{gfw}^{-1}$, respectively) and serpulids (Pomatoceros triqueter $3451.40 \mathrm{~L} \mathrm{~h}^{-1} \mathrm{gfw}^{-1}$, Hydroides norvegica $0.90 \mathrm{~L} \mathrm{~h}^{-1} \mathrm{gfw}^{-1}$, Spirorbis borealis $0.95 \mathrm{~L} \mathrm{~h}^{-1} \mathrm{gfw}^{-1}$ and

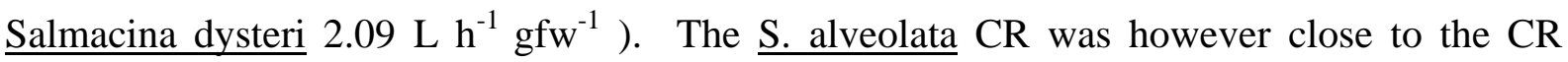
determined by Wells (1970) for the sabellariid Sabellaria kaiparaensis $\left(0.018 \mathrm{~L} \mathrm{~h}^{-1}\right.$ ind $\left.^{-1}\right)$ using the same colloidal graphite suspension as Dales (1957). Sabellariids thus seem to have lower CRs than other suspension-feeding groups represented by sabellids and serpulids, to such an 
extent that sabellariid membership of the suspension-feeding group may be debated (see discussion in Dubois et al., 2006b and Riisgård and Nielsen, 2006). The question of whether

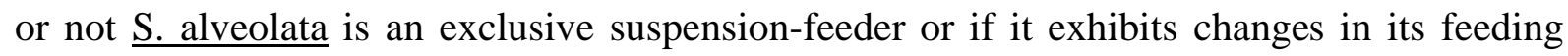
mode (interface-feeder) like spionids (Taghon et al., 1980; Dauer et al., 1981) has still to be addressed.

4.3. Application: estimating the overall filtration pressure of Sabellaria alveolata reefs in the bay of Mont-Saint-Michel

Our approach allowed the extrapolation of reef block CR to overall population

360 filtration pressure. Using reef blocks instead of single tubes provided a realistic simulation of inter-individual behavior and of the number of individuals actually filtering. In addition, the seston loads used in this experiment reproduced the field turbidity measured in the area surrounding the reefs in the bay of Mont-Saint-Michel. Over an 8-day period, Cayocca et al. (2008) recently showed that the turbidity peaked transiently early during the flow (reaching up to $1000 \mathrm{mg} . \mathrm{L}^{-1}$ ) but was around $50 \mathrm{mg} \mathrm{L}^{-1}$ at $30 \mathrm{~cm}$ above the sediment over most of the tide period. The CR calculated for a $225 \mathrm{~cm}^{2}$ reef block with $50 \mathrm{mg} \cdot \mathrm{L}^{-1} \mathrm{SPM}$ could be used to estimate the water volume cleared by all of the $\underline{S}$. alveolata reefs in the bay of Mont-SaintMichel. Hence, considering that $1 \mathrm{~m}^{2}$ of $\underline{\mathrm{S}}$. alveolata reef cleared $46 \mathrm{~L}^{-1} \mathrm{~h}^{-1}\left(1.03 \mathrm{~L} . \mathrm{h}^{-1}\right.$ for a reef block) and also considering that reefs are submerged 13 hours a day for a mean tide (P.

370 Cugier, unpublished data), we estimated the volume cleared each day at $598 \mathrm{~L} \mathrm{~m}^{-2}$. In the bay of Mont-Saint-Michel, S. alveolata reefs spread over 252 ha (i.e. $25210^{4} \mathrm{~m}^{2}$ ) when considering 3D shape and evolutionary stages of the reef (Dubois, 2003): thus the filtration pressure is estimated at $1.3110^{6} \mathrm{~m}^{3}$ day $^{-1}$. This represents the lowest estimate of filtration pressure since the lowest CR value was used in this calculation. A similar calculation using 
$375 \mathrm{CR}$ for $\mathrm{SPM}=6.5 \mathrm{mg} \mathrm{L}^{-1}$ (i.e. $2.96 \mathrm{~L} \mathrm{~h}^{-1}$ ) provides a volume cleared by $\underline{\mathrm{S} \text {. alveolata reefs of }}$ $4.3110^{6} \mathrm{~m}^{3} \mathrm{day}^{-1}$. These values are compared to volumes of cleared water for cultivated

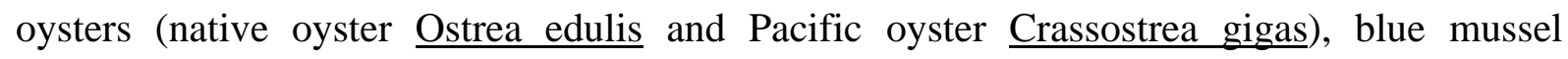
(Mytilus edulis), and invasive slipper limpet (ㄷepidula fornicata) in Table 4 . While the volume cleared per square meter of $\underline{S}$. alveolata reef is far lower than the $100 \mathrm{~m}^{3} \mathrm{~m}^{-2} \mathrm{day}^{-1}$ 380 calculated for dense mussel beds (Jørgensen, 1990), we note that, at the bay scale, the filtration pressure of the reefs is the same order of magnitude as the filtration pressure of the cultivated oyster and mussel populations, as well as the filtration pressure of the remarkably large Lanice conchilega beds (Godet et al., 2008) covering 190 ha in the bay. This shellfish ecosystem is also largely dominated by the invasive species $\underline{C}$. fornicata whose filtration 385 pressure greatly exceeds other benthic compartments and unbalances the trophic web of the bay (Leloup et al., 2008)._ This rough estimate shows that further modeling of the carrying

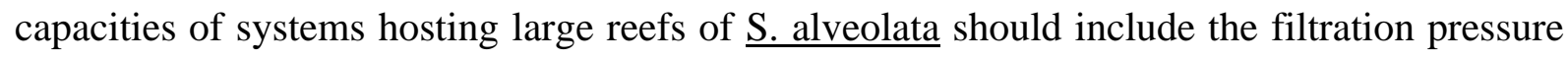
of this polychaete. Many estuarine and marine shellfish environments are colonized by large populations of natural gregarious suspension-feeding polychaetes such as Lanice conchilega

390 (Denis et al., 2007; Godet et al., 2008), Sabella spallanzanii (Licciano et al., 2007) or Ficopomatus enigmaticus (Bruschetti et al., 2008). The influence of large polychaete populations in shallow coastal waters is often underestimated and this study shows that further investigations are needed to determine their ecological role in the coastal food web.

\section{Acknowledgements}

The authors are grateful to P. Rosa for algal cultures and to P. Cugier for estimating the immersion period of Sabellaria alveolata reefs using the bay of Mont-Saint-Michel numerical model. This work was funded by the PNEC (Programme National d'Environnement Côtier) 
project for the bay of Mont-Saint-Michel and supported by a national PhD grant (S. Dubois) from the French Ministry of Education and Research.

\section{References}

405 Barillé, L., Cognie, B., Beninger, P., Decottignies, P., Rince, Y., 2006. Feeding responses of the gastropod Crepidula fornicata to changes in seston concentration. Mar. Ecol. Prog. Ser. 322, 169-178.

Barillé, L., Haure, J., Cognie, B., Leroy, A., 2000. Variations in pallial organs and eulaterofrontal cirri in response to high particulate matter concentrations in the oyster Crassostrea gigas. Can. J. Fish. Aquat. Sci. 57, 837-843.

Barillé, L., Haure, J., Pales-Espinosa, E., Morancais, M., 2003. Finding new diatoms for intensive rearing of the pacific oyster (Crassostrea gigas): energy budget as a selective tool. Aquaculture 217, 501-514.

Barillé, L., Prou, J., Héral, M., Bougrier, S., 1993. No influence of food quality, but rationdependent retention efficiencies in the Japanese oyster Crassostrea gigas. J. Exp. Mar. Biol. Ecol. 171, 91-106.

Barillé, L., Prou, J., Héral, M., Razet, D., 1997. Effects of high natural seston concentrations on the feeding, selection, and absorption of the oyster Crassostrea gigas (Thunberg). J. Exp. Mar. Biol. Ecol. 212, 149-172.

420 Barillé-Boyer, A.-L., Barillé, L., Massé, M., Razet, D., Héral, M., 2003. Correction for particulate organic matter as estimated by loss on ignition in estuarine ecosystems. Est. Coast. Shelf Sci. 58, 147-153. 
Bayne, B.L., Hawkins, A.J.S., Navarro, E., Iglesias, I.P., 1989. Effects of seston concentration on feeding, digestion and growth in the mussel Mytilus edulis. Mar. Ecol. Prog. Ser. 55, 47-54.

Bock, M.J., Miller, D.C., 1996. Fluid flow and suspended particulates as determinants of polychaete feeding behavior. J. Mar. Res. 54, 565-588.

Bricelj, V.M., Malouf, R.E., 1984. Influence of algal and suspended sediment concentrations on the feeding physiology of the hard clam Mercenaria mercenaria. Mar. Biol. 84, 155165.

Bruschetti, M., Luppi, T., Fanjul, E., Rosenthal, A., Iribarne, O., 2008. Grazing effect of the invasive reef-forming polychaete Ficopomatus enigmaticus (Fauvel) on phytoplankton biomass in a SW Atlantic coastal lagoon. J. Exp. Mar. Biol. Ecol. 354, 212-219.

Cayocca, F., Bassoullet, P., Le Hir, P., Jestin, H., Cann, P., 2008. Sedimentary processes in a shellfish farming environment, Mont-Saint-Michel, France. In: Kusuda, T., Yamanishi, H., Spearman, J., Gailani, J.Z. (Eds.), Sediment and Ecohydraulics: INTERCOH Elsevier publishers, Amsterdam, pp. 431-446.

Cloern, J.E., 1982. Does the benthos control phytoplankton biomass in South San Francisco Bay? Mar. Ecol. Prog. Ser. 9, 191-202.

440 Cranford, P.J., Gordon, D.C., 1992. The influence of dilute clay suspensions on sea scallop (Placopecten magellanicus) feeding activity and tissue growth. Netherlands J. Sea Res. 30, 107-120.

Dales, R.P., 1957. Some quantitative aspects of feeding in sabellid and serpulid fan worms. J. Mar. Biol. Ass. U.K. 36, 309-316.

445 Dauer, D.M., Maybury, C.A., Ewing, R.M., 1981. Feeding behavior and general ecology of several spionid polychaetes from the Chesapeake Bay. J. Exp. Mar. Biol. Ecol. 54, 21 38. 
Denis, L., Desroy, N., Ropert, M., 2007. Ambient flow velocity and resulting clearance rates of the terebellid polychaete Lanice conchilega (Pallas, 1766). J. Sea Res. 58, 209-219.

Dubois, S., 2003. Ecologie des formations récifales à Sabellaria alveolata (L.): valeur fonctionnelle et patrimoniale. $\mathrm{PhD}$ thesis, National Museum of Natural History, Paris, pp. 199.

Dubois, S., Barillé, L., Cognie, B., Beninger, P., 2006b. Feeding mechanism of the polychaete

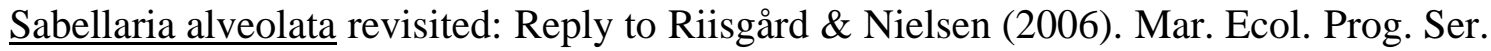
$328,307-311$.

Dubois, S., Barillé, L., Cognie, B., Beninger, P.G., 2005. Particle capture and processing mechanisms in Sabellaria alveolata (Polychaeta: Sabellariidae). Mar. Ecol. Prog. Ser. 301, 159-171.

Dubois, S., Barillé, L., Retiere, C., 2003. Efficiency of particle retention and clearance rate in the polychaete Sabellaria alveolata L. C. R. Biologies 326, 413-421.

Dubois, S., Commito, J.A., Olivier, F., Retiere, C., 2006a. Effects of epibionts on Sabellaria alveolata (L.) biogenic reefs and their associated fauna in the Bay of Mont-SaintMichel. Est. Coast. Shelf Sci. 68, 635-646.

Dubois, S., Retiere, C., Olivier, F., 2002. Biodiversity associated with Sabellaria alveolata (Polychaeta: Sabellariidae) reefs: effects of human disturbances. J. Mar. Biol. Ass. U.K. $82,817-826$.

Duchêne, J.-C., Jordana, E., Charles, F., Grémare, A., 2000. Experimental study of filtration activity in Ditrupa arietina (Annelida Polychaeta) using an automated image analysis system. Oceanologica Acta 23, 805-817.

Dutertre, M., Barillé, L., Haure, J., Cognie, B., 2007. Functional responses associated with pallial organ variations in the Pacific oyster Crassostrea gigas (Thunberg, 1793). J. Exp. Mar. Biol. Ecol. 352, 139-151. 
Eckman, J.E., Duggins, D.O., 1993. Effects of flow speed on growth of benthic suspension feeders. Biol. Bull. 185, 28-41.

475 Ehrhold, A., Guillou, S., Auffret, J.P., Garlan, T., Nguyen, K.D., 2003. Bedload transport modelisation in a bay characterized by a macrotidal environment: example of the MontSaint-Michel Bay (Manche, France). Oceanol. Acta 26, 443-455.

Godet, L., Toupoint, N., Olivier, F., Fournier, J., Retiere, C., 2008. Considering the functional value of common marine species as a conservation stake: The case of sandmason worm Lanice conchilega (Pallas 1766) (Annelida, Polychaeta) beds. Ambio 37, 347-355.

Gruet, Y., 1971. Morphologie, croissance et faune associée des récifs de Sabellaria alveolata (L.) de la Bernerie-en-Retz (Loire Atlantique). Tethys 3, 321-380.

Gruet, Y., Bodeur, Y., 1997. Les récifs d'Hermelles. In: Dauvin, J.C. (Ed.), Les biocénoses marines et littorales françaises des côtes Atlantiques, Manche et Mer du Nord, synthèse, menaces et perspectives. Service du Patrimoine Naturel / IEGB / MNHN Paris Publishers, pp. 168-176.

Haure, J., Penisson, C., Bougrier, S., Baud, J.-P., 1998. Influence of temperature on clearance and oxygen consumption rates of the flat oyster Ostrea edulis: determination of allometric coefficients. Aquaculture 169, 211-224.

490 Hentschel, B.T., Larson, A.A., 2005. Growth rates of interface-feeding polychaetes: combined effects of flow speed and suspended food concentration. Mar. Ecol. Prog. Ser. 293, 119-129.

Holt, T.J., Rees, E.I., Hawkins, S.J., Seed, R., 1998. Biogenic reefs. An overview of dynamic and sensitivity characteristics for conservation management of marine SACs. Scottish Association for Marine Science, UK Marine SACs Project, pp 170.

Iglesias, J.I.P., Urrutia, M.B., Navarro, E., Alvarez-Jorna, P., Larretxea, X., Bougrier, S., Heral, M., 1996. Variability of feeding processes in the cockle Cerastoderma edule (L) 
in response to changes in seston concentration and composition. J. Exp. Mar. Biol. Ecol. 197, 121-143.

Jordana, E., Charles, F., Grémare, A., Amouroux, J.-M., Chrétiennot-Dinet, M.-J., 2001. Food sources, ingestion and absorption in the suspension-feeding polychaete Ditrupa arietina (O. F. Müller). J. Exp. Mar. Biol. Ecol. 266, 219-236.

Jordana, E., Dûchene, J.-C., Charles, F., Grémare, A., Amouroux, J.-M., 2000. Experimental study of suspension-feeding activity in the serpulid polychaete Ditrupa arietina (O.F. Müller). J. Exp. Mar. Biol. Ecol. 252, 57-74.

Jorgensen, C.B., 1990. Bivalves filter feedings: hydrodynamics, bioenergetics, physiology and ecology. Olsen \& Olsen (Eds.), Fredensborg, Denmark.

Le Mao, P., Retiere, C., Le Bec, C., Gerla, D., 2004. Gérer un anthroposystème littoral à forte valeur patrimoniale: comment gérer ce défi en baie du Mont-Saint-Michel? Océanis 30, 95-115.

Leloup, F.A., Desroy, N., Le Mao, P., Pauly, D., Le Pape, O., 2008. Interactions between a natural food web, shellfish farming and exotic species: The case of the bay of MontSaint-Michel (France). Est. Coast. Shelf Sci. 76, 111-120.

Licciano, M., Terlizzi, A., Giangrande, A., Cavallo, R.A., Stabili, L., 2007. Filter-feeder macroinvertebrates as key players in culturable bacteria biodiversity control: A case study with Sabella spallanzanii (Polychaeta: Sabellidae). Mar. Env. Res. 64, 504-513.

Navarro, J.M., Widdows, J., 1997. Feeding physiology of Cerastoderma edule in response to a wide range of seston concentrations. Mar. Ecol. Prog. Ser. 152, 175-186.

Newell, C.R., Wildish, D.J., MacDonald, B.A., 2001. The effects of velocity and seston concentration on the exhalant siphon area, valve gape and filtration rate of the mussel Mytilus edulis. J. Exp. Mar. Biol. Ecol. 262, 91-111. 
Palmer, R.E., Williams, R.E., 1980. Effect of particle concentration on filtration efficiency of the bay scallop Argopecten irradians and the oyster Crassostrea virginica. Ophelia 10, $17-25$.

525 Prins, T.C., Dankers, N., Smaal, A.C., 1994. Seasonal variation in the filtration rates of a semi-natural mussel bed in relation to seston composition. J. Exp. Mar. Biol. Ecol. 176, 69-86.

Riisgård, H.U., 2001. On measurement of filtration rates in bivalves - the stony road to reliable data: review and interpretation. Mar. Ecol. Prog. Ser. 211, 275-291.

Riisgård, H.U., Grémare, A., Amouroux, J.M., Charles, F., Vétion, G., Rosenberg, R., Nielsen, C., 2002. Comparative study of water-processing in two ciliary filter-feeding polychaetes (Ditrupa arietina and Euchone papillosa) from two different habitats. Mar. Ecol. Prog. Ser. 229, 113-126.

Riisgård, H.U., Kittner, C., Seerup, D.F., 2003. Regulation of opening state and filtration rate in filter-feeding bivalves (Cardium edule, Mytilus edulis, Mya arenaria) in response to low algal concentration. J. Exp. Mar. Biol. Ecol. 284, 105-127.

Riisgård, H.U., Nielsen, C., 2006. Feeding mechanism of the polychaete Sabellaria alveolata revisited: comment on Dubois et al. (2005). Mar. Ecol. Prog. Ser. 328, 295-305.

Ropert, M., Goulletquer, P., 2000. Comparative physiological energetics of two suspension feeders: polychaete annelid Lanice conchilega (Pallas 1766) and Pacific cupped oyster Crassostrea gigas (Thunberg 1795). Aquaculture 181, 171-189.

Shumway, S.E., Cucci, T.L., Newell, R.C., Yentsch, C.M., 1985. Particle selection, ingestion, and absorption in filter-feeding bivalves. J. Exp. Mar. Biol. Ecol. 91, 77-92.

Taghon, G.L., Nowell, A.R.M., Jumars, P.A., 1980. Induction of suspension feeding in spionid polychaetes by high particulate fluxes. Science $210,562-564$.

Wells, R.M.G., 1970. The feeding biology of Sabellaria. Tane 16, 131-134. 
Fig. 1. Location of Sabellaria alveolata reefs within the bay of Mont-Saint-Michel (black circles). Note the spread of the cultivated oyster and mussel beds.

555 Fig. 2. Experimental set-up with details of the troughs containing Sabellaria alveolata reef blocks. Diagram of troughs modified from Dubois et al. (2003).

Fig. 3. Standardization using image processing software Adobe ${ }^{\circledR}$ Photoshop-CS $3^{\circledR}$ to determine the number of filtering individuals. (a) initial picture of reef surface; (b) picture of reef surface reshaped to the size of the reef block (i.e. $15 \mathrm{~cm} \mathrm{x} 15 \mathrm{~cm}$ ); (c) map of all tube apertures; (d) reference map of tube apertures (empty circles) superimposed on each picture of the set; (e) determination of filtering and non-filtering individuals; (f) final pattern of filtering individuals.

565 Fig. 4. Standardization using image processing software Adobe ${ }^{\circledR}$ Photoshop-CS3 ${ }^{\circledR}$ to determine the difference in the number of filtering individuals between 2 successive pictures. (a) map of filtering individuals, represented by gray dots, for one picture; (b) map of filtering individuals for the following picture; (c) superimposition of the two successive pictures; individuals that did not switch between filtering and non-filtering modes appear as black dots; (d) removal of non-switching individuals and counting of individuals that switched between the two modes. 
Fig. 5. (a) Percentage of filtering polychaetes according to SPM concentration for the first 3 experimental conditions $\left(\mathrm{C} 1=6.5 \mathrm{mg} \mathrm{L}^{-1}, \mathrm{C} 2=12.3 \mathrm{mg} \mathrm{L}^{-1}, \mathrm{C} 3=55.5 \mathrm{mg} \mathrm{L}^{-1}\right)$; (b)

575 Percentage of polychaetes switching from a feeding to a non-feeding mode (and vice versa) between two successive pictures for the first 3 experimental conditions.

Fig. 6. Example of particle size spectra at the outflow of the troughs showing Skeletonema

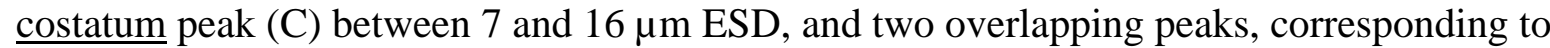
an emission of spermatozoa (A) between 2 and $4 \mu \mathrm{m}$ ESD and to the Kaolinite peak (B) between 4 and $5 \mu \mathrm{m}$ ESD. To facilitate representation, the volume of particles (in $\mathrm{mm}^{3} \cdot \mathrm{mL}^{-1}$ ) was used as a unit.

Fig. 7. Mean clearance rates ( $\mathrm{n}=5$; SE bars are shown) of Sabellaria alveolata calculated according to five experimental conditions, with increasing suspended particulate matter. Black bars represent non-standardized clearance rates of reef blocks and gray bars represent standardized clearance rates of reef blocks adjusted to the number of actual filtering individuals. Letters indicate significant post-hoc comparison results.

Fig. 8. Variations in mean individual clearance rates $(n=5 ;$ SE bars are shown $)$ of Sabellaria alveolata fitted against SPM using an exponential decay curve. 


\section{Table 1}

Characteristics of experimental diets (C1 to $\mathrm{C} 5)$ supplied to Sabellaria alveolata.

\begin{tabular}{lccc}
\hline & SPM & POM & PIM \\
mean (SE) & mean (SE) & mean (SE) \\
\hline C1 & $6.5(0.4)$ & $3.2(0.2)$ & $3.3(0.2)$ \\
C2 & $12.3(1,5)$ & $2.9(0.4)$ & $9.5(1.1)$ \\
C3 & $55.5(1.0)$ & $2.6(0.2)$ & $52.9(0.9)$ \\
C4 & $102.7(1.0)$ & $10.6(0.7)$ & $92.1(0.4)$ \\
C5 & $153.8(2.1)$ & $13.2(3.9)$ & $140.6(1.9)$ \\
& & & \\
\hline
\end{tabular}

SPM: suspended particulate matter $\left(\mathrm{mg} \mathrm{L}^{-1}\right)$; POM: particulate organic matter $\left(\mathrm{mg} \mathrm{L}^{-1}\right)$; PIM: particulate inorganic matter $\left(\mathrm{mg} \mathrm{L}^{-1}\right)$. Data presented are means of three replicates per experimental condition (SE: standard error). POM was constituted by the diatom

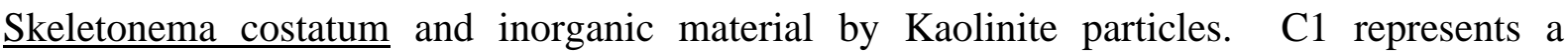
600 condition without Kaolinite, the inorganic matter having originated from the microalgae frustules. 
Table 2

605 Number of polychaetes in each reef block $(15 \mathrm{~cm} \times 15 \mathrm{~cm})$ estimated and counted after destruction of all tubes. Total weight obtained after $48 \mathrm{~h}$ at $60^{\circ} \mathrm{C}$.

\begin{tabular}{lccccc}
\hline${\text { Reef block } \mathrm{n}^{\circ}}^{\circ}$ & 1 & 2 & 3 & 4 & 5 \\
\hline Counted number of individuals $\left(\mathrm{n}^{\circ}\right.$ ind $)$ & 607 & 559 & 601 & 549 & 567 \\
Estimated tube aperture $\left(\mathrm{n}^{\circ}\right.$ ind $)$ & 593 & 552 & 581 & 510 & 558 \\
Error estimated / counted $(\%)$ & 2.31 & 1.25 & 3.33 & 7.10 & 1.59 \\
Total dry weight $(\mathrm{g})$ & 3.62 & 3.19 & 2.98 & 3.15 & 2.99 \\
\hline
\end{tabular}

610 


\section{Table 3}

Percentages (mean $\pm \mathrm{SE} ; \mathrm{n}=10$ ) of filtering individuals and individuals switching from a feeding to a non-feeding mode, in relation to experimental conditions. Because of light penetration, counting was only carried out for experimental conditions up to SPM $=55.5 \mathrm{mg}$ $615 \mathrm{~L}^{-1} 1$.

\begin{tabular}{cccc}
\hline & \multicolumn{3}{c}{ Suspended Particulate Matter } \\
& $\mathrm{C} 1=6.5 \mathrm{mg} \mathrm{L}^{-1}$ & $\mathrm{C} 2=12.3 \mathrm{mg} \mathrm{L}^{-1}$ & $\mathrm{C} 3=55.5 \mathrm{mg} \mathrm{L}^{-1}$ \\
\hline $\begin{array}{c}\text { Filtering individuals (mean \%) } \\
\text { Variations between 2 }\end{array}$ & $43.2 \pm 0.81$ & $46.3 \pm 0.93$ & $47.4 \pm 1.0$ \\
successive pictures (mean \%) & $6.12 \pm 0.38$ & $6.79 \pm 0.35$ & $7.67 \pm 0.49$ \\
\hline
\end{tabular}




\section{Table 4}

Estimates of the filtration pressure of the main intertidal suspension-feeding cultivated and natural species in the bay of Mont-Saint-Michel.

\begin{tabular}{|c|c|c|c|c|c|c|c|}
\hline & \multicolumn{2}{|c|}{ Biomass $^{(1)}$} & \multirow{2}{*}{$\begin{array}{c}\mathrm{CR} \\
\left(\mathrm{L} \mathrm{h}^{-1}\right. \\
\left.\mathrm{gdw}^{-1}\right)\end{array}$} & \multirow[t]{2}{*}{ Food source } & \multirow{2}{*}{$\begin{array}{c}\mathrm{T} \\
\left({ }^{\circ} \mathrm{C}\right)\end{array}$} & \multirow{2}{*}{$\begin{array}{l}\text { Immersion } \\
\left(\mathrm{h} \mathrm{day}^{-1}\right)\end{array}$} & \multirow{2}{*}{$\begin{array}{c}\text { Filtration } \\
\text { pressure } \\
\left(10^{6} \mathrm{~m}^{3}\right. \\
\left.\text { day }^{-1}\right)\end{array}$} \\
\hline & $\begin{array}{r}(\mathrm{t} \text { fresh } \\
\text { weight })\end{array}$ & $\begin{array}{c}\text { (t dry } \\
\text { weight) }\end{array}$ & & & & & \\
\hline $\begin{array}{l}\text { Pacific oyster } \\
\text { Crassostrea gigas }\end{array}$ & 2025 & 30.7 & $4.2^{(3)}$ & Natural & 17 & 13 & 1.67 \\
\hline $\begin{array}{l}\text { European flat oyster } \\
\text { Ostrea edulis }\end{array}$ & 615 & 9.5 & $0.6^{(4)}$ & $\frac{\text { Skeletonema }}{\text { costatum }}$ & 15 & 24 & 0.14 \\
\hline $\begin{array}{l}\text { Blue mussel } \\
\text { Mytilus edulis }\end{array}$ & 6900 & 271.4 & $1.5^{(5)}$ & Natural & 16 & 13 & 5.28 \\
\hline $\begin{array}{l}\text { Slipper limpet } \\
\text { Crepidula fornicata }\end{array}$ & 136650 & 6828.5 & $0.76^{(6)}$ & $\begin{array}{c}\frac{\text { Nitzschia }}{\text { aurariae and }} \\
\text { Entomoneis } \\
\text { pseudoduplex }\end{array}$ & 15 & 24 & 124.57 \\
\hline $\begin{array}{l}\text { Sandmason worm } \\
\text { Lanice conchilega }\end{array}$ & $1181^{(2)}$ & $169^{(2)}$ & $0.4^{(7)}$ & $\frac{\text { Chaetoceros }}{\underline{\text { calcitrans }}}$ & 18 & 13 & 0.88 \\
\hline $\begin{array}{l}\text { Honeycomb worm } \\
\text { Sabellaria alveolata }\end{array}$ & 1570 & 287 & $0.35^{(8)}$ & $\frac{\text { Skeletonema }}{\text { costatum }}$ & 15 & 13 & 1.31 \\
\hline
\end{tabular}

625

${ }^{(1)}$ Unless otherwise stated, biomass data originates from the French National Program of Coastal Environment (extracted from Leloup et al., 2008); ${ }^{(2)}$ Godet et al., 2008; ${ }^{(3)}$ Ropert and Goulletquer, 2000; ${ }^{(4)}$ Haure et al., 1998; ${ }^{(5)}$ Prins et al., 1994; ${ }^{(6)}$ Barillé et al., 2006; ${ }^{(7)}$ Denis et al, 2007 (data for large individuals); ${ }^{(8)}$ this study. Immersion period for C. gigas, $\underline{\text { M. edulis }}$

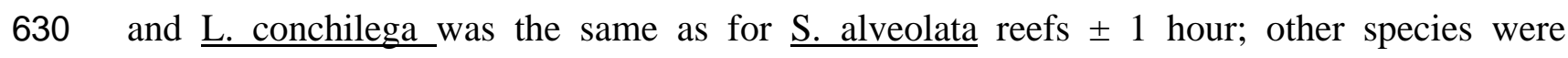
immersed for 24 hours a day. 


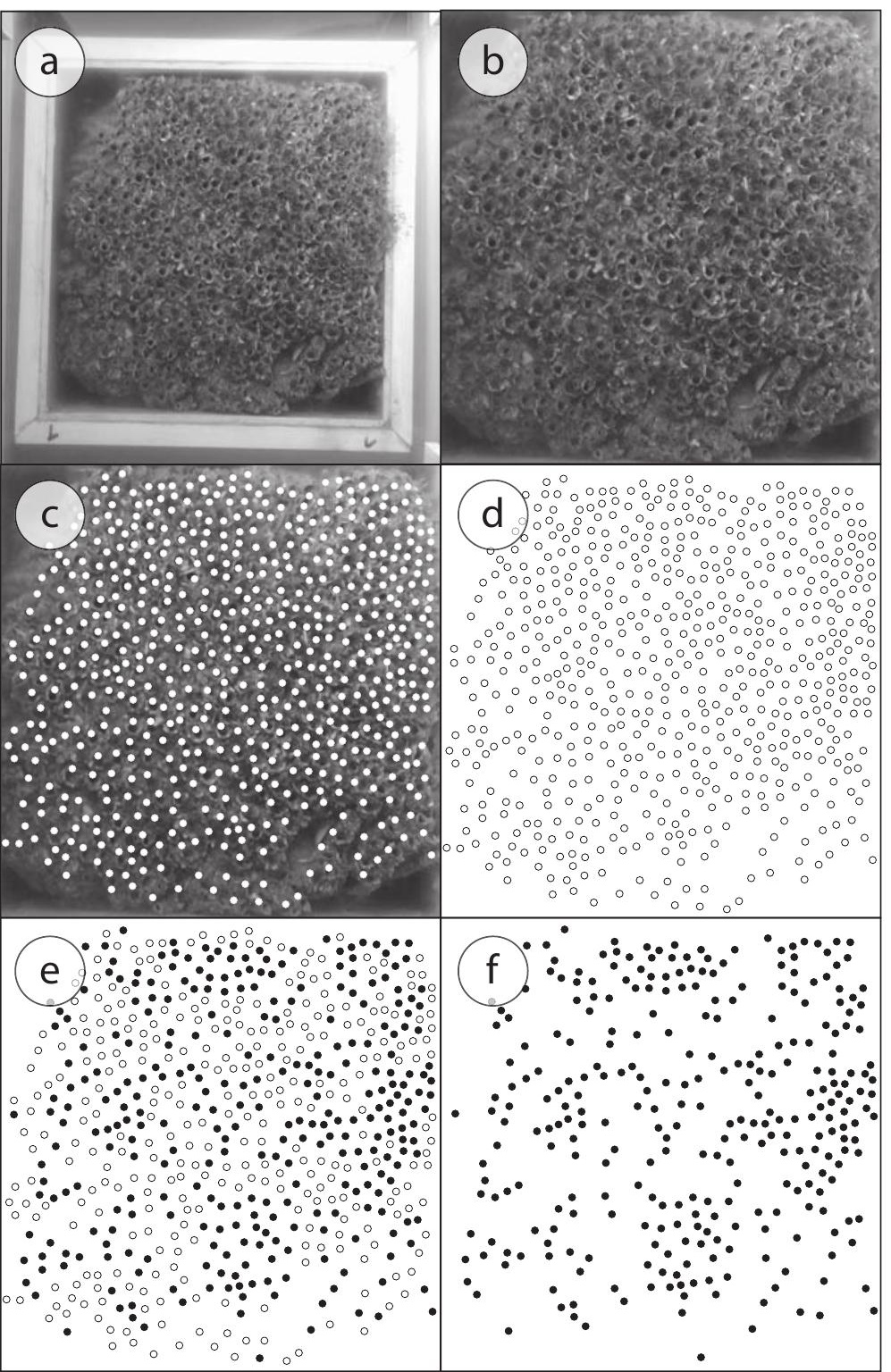




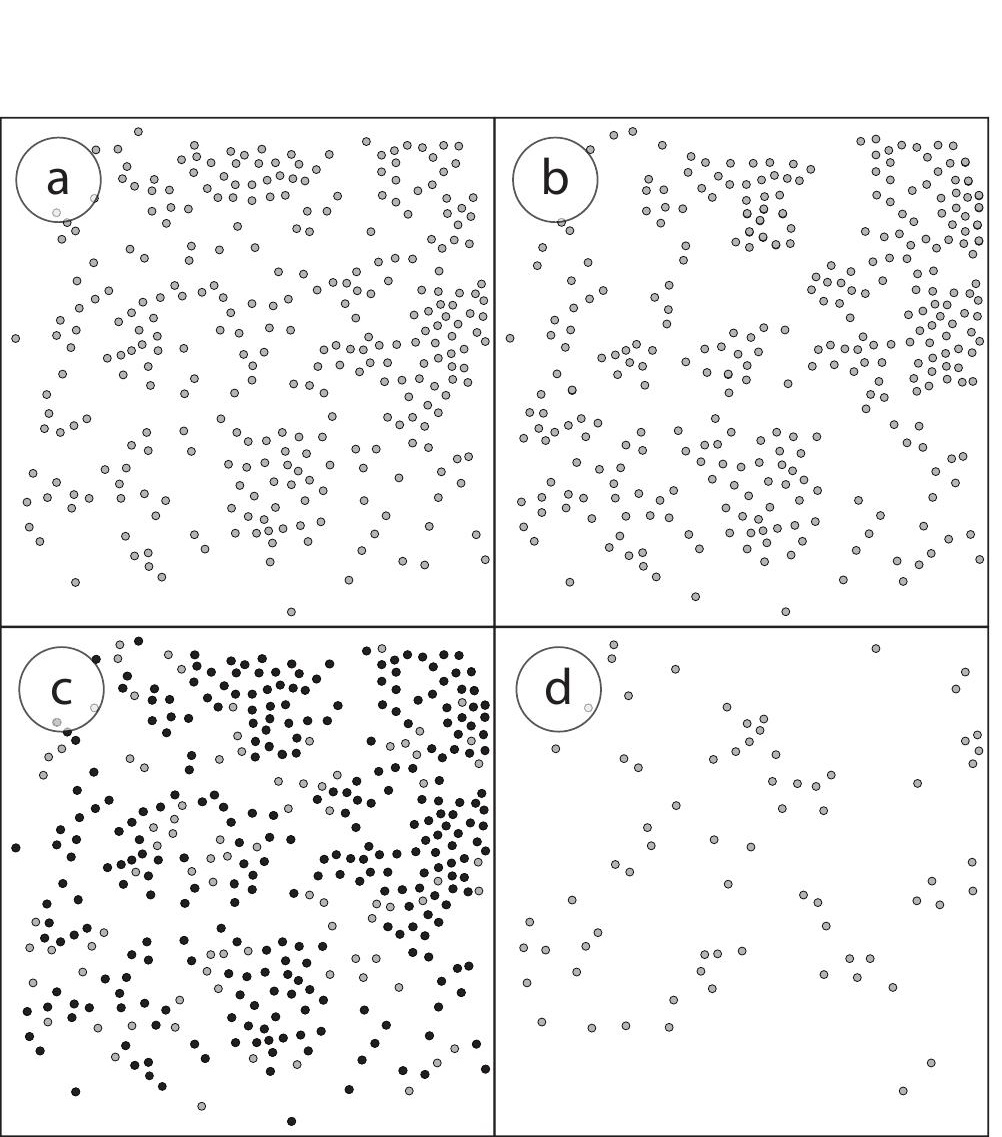

Figure 4 
Figure 5

60

a $\longrightarrow \mathrm{C} 1\left(6.5 \mathrm{mg} \mathrm{L}^{-1}\right)$

- $-\mathrm{C} 2\left(12.3 \mathrm{mg} \mathrm{L}^{-1}\right)$

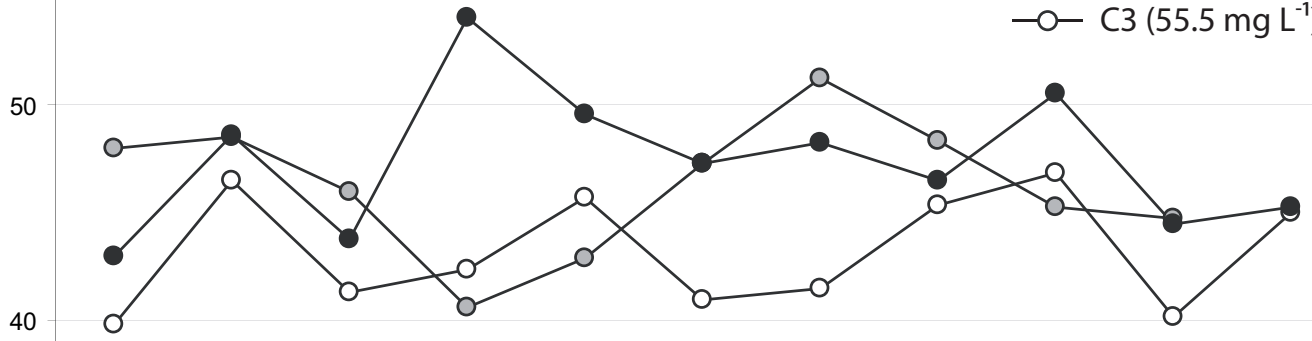

0
$6 \quad 12 \quad 18$
$24 \quad 30 \quad 36$
$42 \quad 48$
$54 \quad 60 \quad 64$

Time after beginning of experiment ( $\mathrm{min})$

15
(b)
$\rightarrow C 1\left(6.5 \mathrm{mg} \mathrm{L}^{-1}\right)$
$-0-C 2\left(12.3 \mathrm{mg} \mathrm{L}^{-1}\right)$
- - C3 (55.5 $\left.\mathrm{mg} \mathrm{L}^{-1}\right)$

5

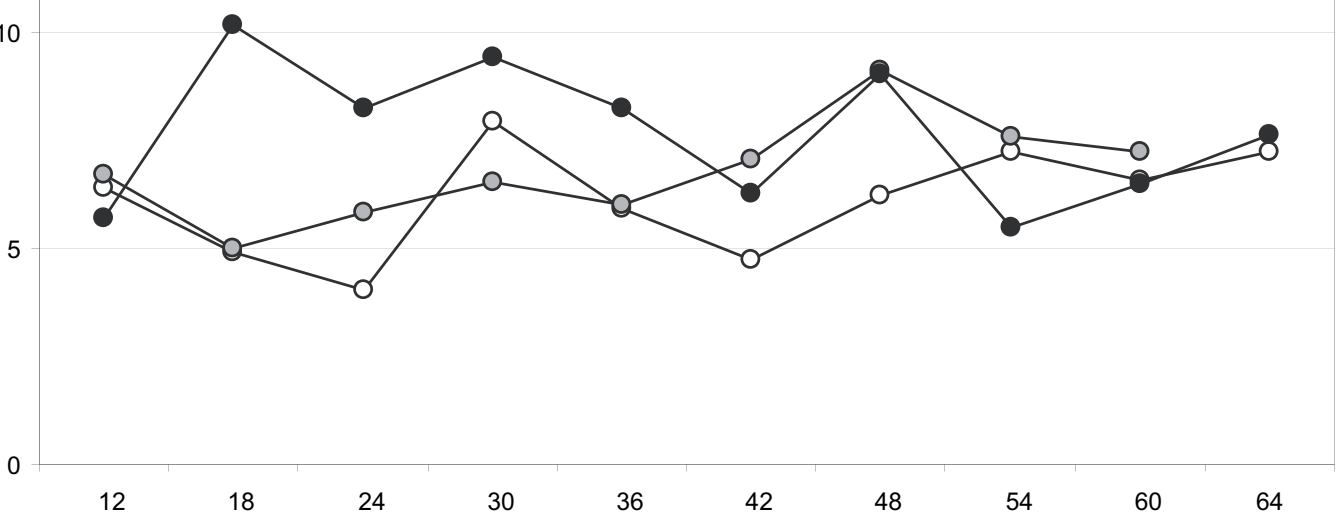

time after beginning of experiment (min) 
Figure 6

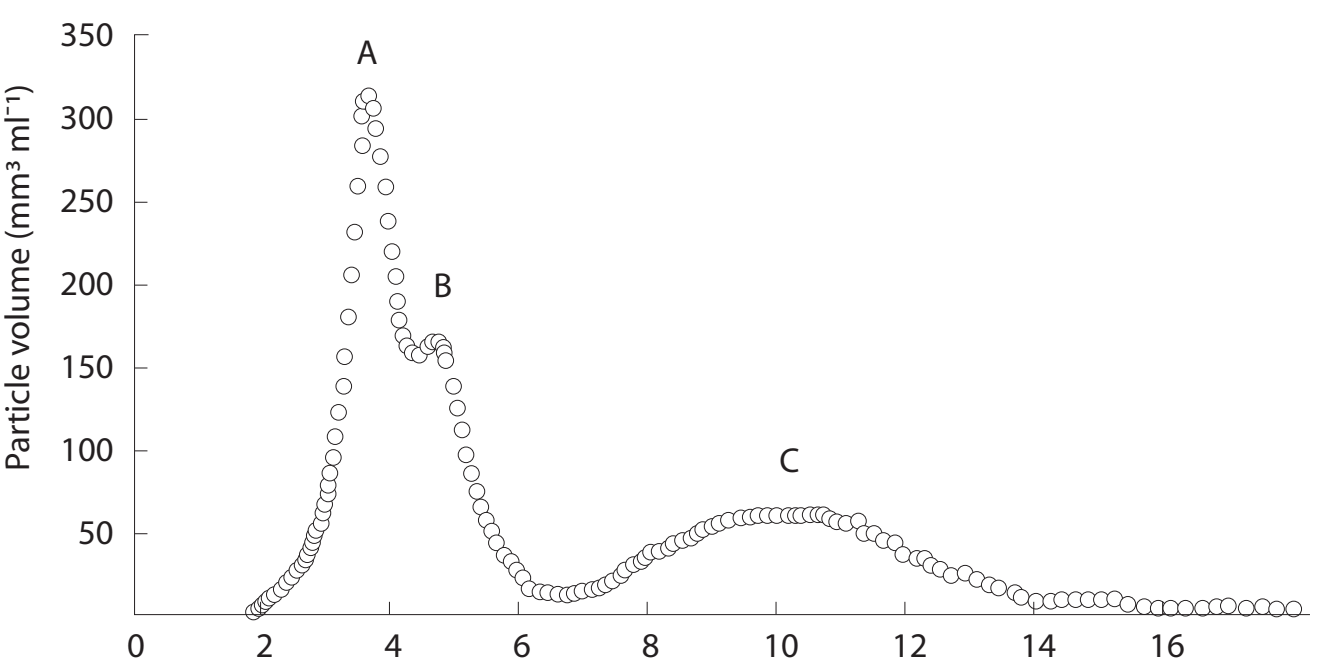

Equivalent Spherical Diameter $(\mu \mathrm{m})$ 
Figure 7

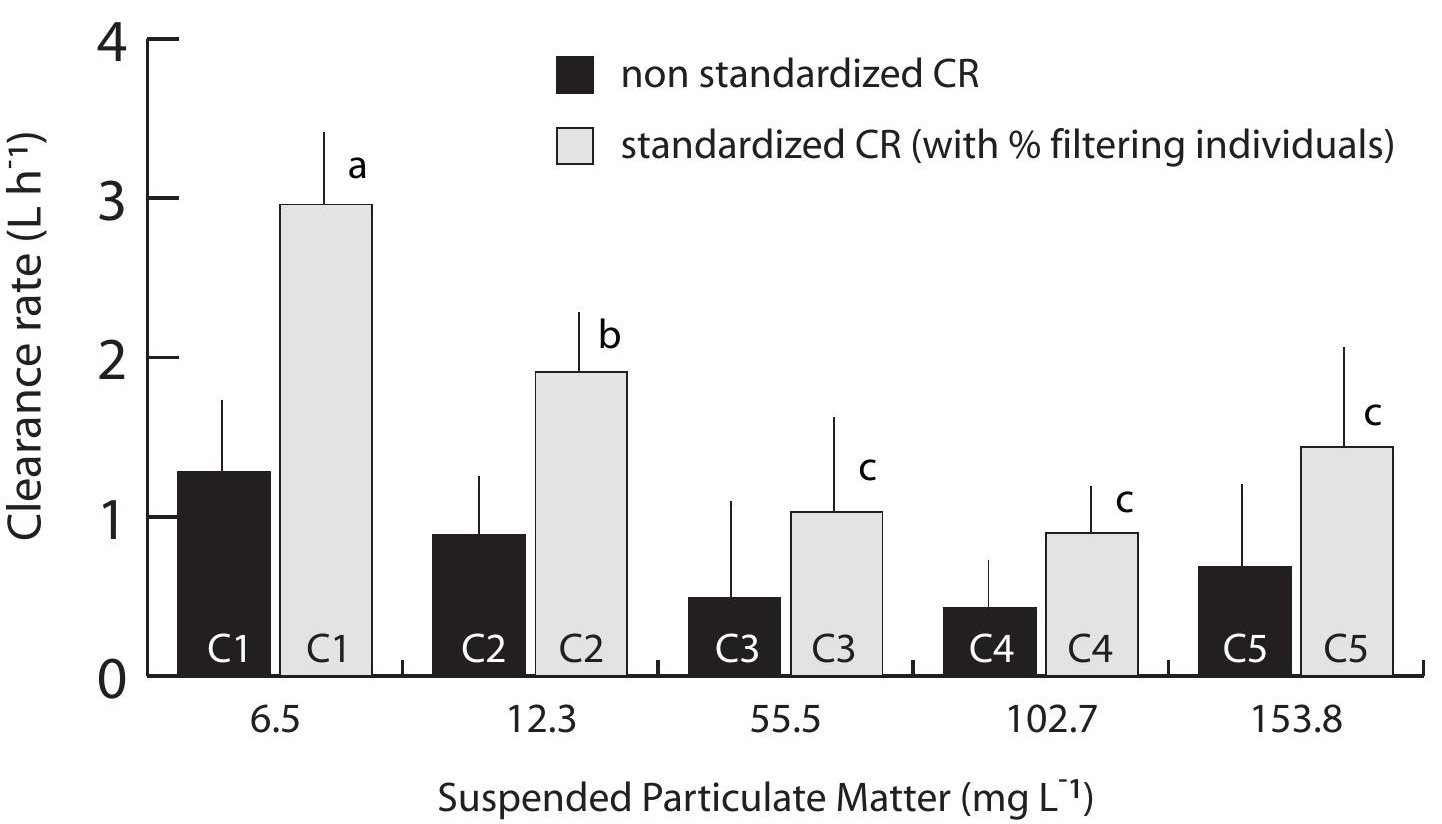


